\title{
Shaping regional strategies of multinational corporations
}

\begin{abstract}
This paper examines the factors that drive the success of multinational corporations (MNCs) in their pursuit of regional strategies. We develop a comprehensive regional success factor model to investigate the effects of regional management autonomy and regional product/service adaptation on the regional success of MNCs. Using structural equation modeling, we also analyze the interaction effects of regional orientation and inter-regional distance. We evaluate our model by means of both primary and secondary data for Fortune Global 500 firms. Our findings show that appropriate degrees of regional management autonomy and regional product/service adaptation are highly contingent upon contextual influences on MNCs.
\end{abstract}




\section{INTRODUCTION}

The recent literature on regional multinationals (Rugman, 2005; Rugman and Verbeke, 2008a) has proposed regional strategies to multinational corporations (MNCs) as a promising alternative to earlier internationalization strategies that build on the concepts of global integration and local responsiveness (e.g., Bartlett and Ghoshal, 1989; Prahalad and Doz, 1987). The increased strategic importance of the region for MNCs, as an intermediate geographical level in between the traditional world-country dichotomy, is largely attributed to changing patterns in both world trade and foreign direct investment (FDI) over time - particularly the development of the broad triad regions of North America, Europe, and Asia (Ohmae, 1985; Rugman, 2000; Rugman and Hodgetts, 2001a). Thus the relevance of regional strategies is supported by observations of an incomplete cross-border integration for different types of markets (i.e., for products, capital, labor, and knowledge), referred to as semiglobalization, where both the barriers and the links among these markets explain the regional expansion of MNCs (Ghemawat, 2003, 2005, 2007). This trend is reflected in regional sales data for Fortune Global 500 firms showing that most MNCs do not achieve a truly global sales dispersion because they are regionally oriented, mainly towards their home region (Rugman, 2003b; Rugman and Verbeke, 2004c). Although considerable evidence highlights the existence and increasingly important role of regional strategies for MNCs, to the best of our knowledge, no empirical study has provided a clear answer to the question of how to actually develop and implement a regional strategy in a successful manner.

This research gap is mainly because much scholarly work on regionalization focuses either on the different phenomena of regional strategies (e.g., Girod and Rugman, 2005; Li, 2005; Yin and Choi, 2005) or on their outcome, such as the geographical distribution of sales and assets (e.g., Collinson and Rugman, 2008; Oh, 2009) or the regional performance of MNCs (e.g., Yip, Rugman, and Kudina, 2006). However, in existing combinations of these two research fields, leading to a regional 
strategy-performance relationship, a foundation in organization theory is largely missing in the international business literature. Few authors have considered the organizational context of MNCs, and thereby the fact that the relationship between regional strategies and MNC performance is contingent on conditions and developments inside and/or outside of the firm (e.g., Bausch, Fritz, and Boesecke, 2007; Goerzen and Asmussen, 2007). Furthermore, existing empirical studies about the performance of regional strategies largely focus on relative figures of regional data - for example, regional sales divided by total sales or return on sales (e.g., Li and Li, 2007; Rugman and Oh, 2007). This methodology based on secondary data analyses may be eye opening for regional performance phenomena, but it is not able to explore their causal influences.

The aim of this paper is to address these challenges by examining the factors that drive the success of MNCs in their pursuit of regional strategies. A promising path for conceptualizing such factors is provided by the recent academic work on regional strategies, where autonomous management at the regional level and product/service adaptations to regional market requirements characterize a regional strategy (Rugman, 2005). Besides these basic elements of regional strategies, we aim to consider contextual influences in the regional strategy-performance relationship, resulting in a contingency perspective for the explanation of the success of the regional strategies of MNCs. To investigate these causal relationships, we develop a regional success factor model and explore the interactions of regional success factors with MNC performance. Apart from these conceptual contributions, we also want to extend existing knowledge in methodological terms by collecting not only secondary but also primary data for Fortune Global 500 firms. In assessing the regional success of these MNCs, we want to consider various regional success indicators, which are derived from longitudinal data over nine financial reporting periods (2000-2008). Furthermore, we aim to analyze the relationships in a regional success factor model with structural equation modeling (SEM) on the 
basis of the partial least squares (PLS) method, which has not yet been used to study the regional strategies of MNCs and their performance.

Thus, we take a differentiated multidimensional view that links theoretical insights about the main elements of regional strategies - regional management autonomy and regional product/service adaptation - to regional performance research and the contingency approach. In combination with our research methodology that allows the test of causal relationships, we can examine the degree of these two characterizing factors of regional strategies that is appropriate for MNCs to achieve superior regional performance - which thereby leads to their classification as regional success factors of MNCs. For MNC managers, the knowledge of such managerial and product-/servicerelated success factors is crucial to properly translate regional strategies into corporate performance. Therefore, while the conceptual and methodological underpinnings of our study should ensure rigorous research, the respective findings should also deliver relevant information for the managerial practice of MNCs.

The remainder of this paper is structured as follows. In the next section, we briefly review the literature on regional strategies and their constituting elements: regional management autonomy and regional product/service adaptation, and regional contextual influences. We then develop hypotheses on these relationships to derive our regional success factor model. Subsequently, we outline the research design and research methodology to empirically test our hypotheses. After presenting the empirical results, we conclude with a discussion of the implications of our findings, the limitations of our study, and some suggestions for further research. 


\section{LITERATURE REVIEW}

\section{Regional Strategies}

Regional strategies emerged particularly in the 1990s, with the development of trading blocs such as the EU, AFTA, and NAFTA that enabled MNCs to benefit from growing FDI opportunities inside their own regions (Morrison, Ricks, and Roth, 1991; Rugman and Verbeke, 1998; Westney, 2006). Although such free trade zones have still benefited from the positive effects of external FDI (Buckley et al., 2001; Feils and Rahman, 2008), the economic data show that, at the same time, intra-regional trade and FDI have increased significantly (Dunning, 2001; Rugman, 2000; Rugman et al., 2001a). Along with these developments, MNCs have continued to adjust their strategies and organizational designs, to relocate their subsidiaries, and to align their product-/service-related and functional market interfaces to the requirements of their geographic markets (Doz and Prahalad, 1991). For the cross-border configuration of these corporate activities, regionalization does suggest MNCs should exploit their strengths and determine their competitive strategies separately for each region (Morrison et al., 1991). When firms pursue a regional strategy respective regions become the primary organizational focus of their activities and management is required to recognize fully the nature and changing conditions of the host regions. As a result, MNCs are advised to design strategies on a regional rather than a global basis (Rugman, 2003a; Rugman et al., 2001a; Rugman and Moore, 2001b).

Such regional strategies of MNCs require a market strategy approach tailored to regional conditions and the creation of region-based components in the MNC's "[...] coordination and control structure to address the specific managerial challenges in those regions" (Rugman, 2005). The regional dimension in MNC strategies thereby implies a decomposition of MNCs' strategic decision-making processes and their product/service offering into global, regional, and national components 
(Rugman, 2005; Rugman et al., 2008a). This is illustrated in Rugman's (2005) regional strategy matrix, where MNCs following a regional strategy are characterized by a high degree of regional management autonomy and the regional adaptation of products/services. Within their regional environments, by means of these region-based adaptation strategies and organizational structures, MNCs can achieve both regional responsiveness and regional integration benefits (Rugman, 2005; Rugman et al., 2008a). Therefore, the regional strategy matrix effectively illustrates a regional environment-strategy-structure relationship.

\section{Regional Management Autonomy}

In the literature, different reasons are brought forward for installing autonomous regional management in MNCs. Based on transaction cost theory some argue that regional management represents an efficient intra-firm governance mechanism for the bounded rationality and bounded reliability of MNCs in their management of numerous national subsidiaries (Arregle, Beamish, and Hébert, 2009; Rugman and Verbeke, 2005; Verbeke and Kenworthy, 2008). Others argue that MNCs need to create a favorable organizational context fitting to their external environment when trying to deploy non-location-bound and location-bound knowledge and innovations (Verbeke et al., 2008). Furthermore, regional management is an organizational response of MNCs to balance the pressures to stay local and to globalize (Buckley and Ghauri, 2004; Enright, 2005a). These two conflicting pressures affect a firm's functional activities along its value chain, because they impose the need for both customer-end (or downstream) and back-end (or upstream) firm-specific advantages (FSAs) on MNCs (Rugman, 2005; Rugman et al., 2008a). The deployment of customerend and back-end FSAs, however, is irrespective of a particular value chain function (Rugman, 2005). As a result, the geographical division of corporate functions along MNCs' value chains represents the appropriate unit of analysis for regional management (Buckley et al., 2004). Based on 
an analysis of Enright's empirical studies (2005a, 2005b) we can identify the four most important categories of regional management activities: regional strategy development, regional market and product/service development, regional market coordination, and regional operational administration.

\section{Regional Product/Service Adaptation}

It has been argued that the products and services of MNCs often are regionally adapted to specific market requirements and conditions at the regional level, particularly to satisfy regional customer demands (Rugman, 2005; Rugman et al., 2008a). In addition, the regional level becomes increasingly important for product/service adaptations in the EU and North America but also in Asia, driven by attempts at institutional convergence and a reduction of trade and investment barriers. For Rugman and Verbeke (2008b), “[...] industry competition thus increasingly occurs at the regional level, rather than the national level." An $\mathrm{MNC}$ 's regional adaptation of its products/services, therefore, is a form of market responsiveness to achieving a unique competitive position as a regional insider (Ohmae, 1985; Rugman et al., 2004c). The extent to which a product/service is regionally adapted thereby heavily depends upon the geographic reach of its embodied FSAs (Rugman, 2005; Verbeke, 2009). Such region-bound FSAs are company strengths beyond the limited geographic scope of a single country, while they are still location-bound within the countries of a particular region (Morrison et al., 1991; Morrison and Roth, 1992; Rugman, 2005). More specifically, a regional product/service results either from augmenting the geographic reach of location-bound FSAs to the regional level or from the regionally limited deployability of non-location-bound FSAs (Rugman, 2005; Verbeke, 2009). This is why the regional adaptation of products/services involves intra-regional resource commitments in the form of investments in foreign markets and subsidiaries (Rugman, 2005). The result of such region-specific adaptation 
investments is a linkage of the MNC's existing (non-location-bound and location-bound) FSAs with its country-specific advantages (CSAs) in the form of regional/locational advantages (Rugman, 2005; Rugman and Verbeke, 2001c; Rugman et al., 2004c, 2008a).

Regional FSAs result from regional competencies of an MNC concerning the core customer benefits and characteristics of an actual product/service offering such as features, design, packaging, quality level, and brand name (Kotler and Armstrong, 2004; Rugman, 2005). A combination of the different forms of regional product/service adaptations (Keillor, Hult, and Kandemir, 2004; Onkvisit and Shaw, 2009; Takeuchi and Porter, 1986) with the reasons for adapting products/services to regional demands (De Búrca, Fletcher, and Brown, 2004; Onkvisit et al., 2009), leads to four broad categories: design, functional scope, brands, and offering portfolio (Figure 1). These four categories reflect the main types of regional product/service adaptations according to the international marketing literature (De Búrca et al., 2004; Kotabe and Jiang, 2009; Kotler et al., 2004; Onkvisit et al., 2009).

$<<$ place Figure 1 about here $>>$

\section{Regional Contextual Influences}

According to contingency theory (Donaldson, 2001), the organizational effectiveness of an MNC can be explained as a function of the fit of its strategy and structure with its internal and external contingencies (Zeithaml, Varadarajan, and Zeithaml, 1988). Applied to regional MNCs, the simultaneous achievement of intermediate degrees of integration and responsiveness at the regional level is contingent upon their particular regional environment-strategy-structure relationship. According to the more recent literature on regionalization (Ghemawat, 2001, 2008; Proff, 2002; 
Rugman, 2005; Rugman et al., 2004c, 2008a), two regional contextual influences particularly affect this relationship: an MNC's regional orientation and the inter-regional distance it faces.

Regional orientation is a form of the geographic orientation of MNCs in contrast to local or global orientation (Banalieva and Santoro, 2009). It relates to a certain focus of senior management in the geographic expansion of MNCs (Delios and Beamish, 2005; Rugman, 2005). Specifically, it reflects a firm-internal, regiocentric orientation of MNC managers, who mainly view the region as a potential market (Proff, 2002; Wind, Douglas, and Perlmutter, 1973), resulting in a narrow geographic market focus (Rugman et al., 2008a) and a selectivity in the geographic scope of activities (Rugman, 2005; Rugman et al., 2004c). The regional orientation of an MNC is an important internal contingency variable in the relationship between an MNC's regional strategy and/or structure components and the achievement of its corporate goals and objectives (Rugman, 2005).

In addition, regional MNCs have to consider the costs and risks of inter-regional distance in the economic evaluation of their international growth plans (Ghemawat, 2001; Rugman, 2005). Interregional distance comprises cultural, administrative/political/institutional, geographic, and economic dimensions (Ghemawat, 2001; Ricart et al., 2004; Rugman, 2005), as illustrated in the so-called "CAGE framework" (Table 1, Appendix). The inter-regional distance faced by a particular MNC may result in a competitive disadvantage from its liability of foreignness in the form of the additional costs of doing business abroad (Zaheer, 1995, 2002). Inter-regional distance, therefore, is an important external contingency variable in the achievement of an MNC's corporate objectives, particularly regarding adaptation, aggregation, and arbitrage benefits from regional strategystructure combinations (Arregle et al., 2009; Buckley et al., 2004; Rugman, 2005). 


\section{HYPOTHESES AND REGIONAL SUCCESS FACTOR MODEL}

As indicated above, the regional performance and overall competitiveness of MNCs is influenced by the regional environment-strategy-structure fit. More specifically, the regional success factors of MNCs - given by appropriate degrees of managerial decision-making autonomy and regional product/service adaptation - are highly internally contingent upon their regional orientation and highly externally contingent upon the inter-regional distance they face. A graphical illustration of these theoretically derived, causal relationships leads to a regional success factor model (Figure 2). The specific hypotheses underlying the model will be elaborated in the following section.

$$
<<\text { place Figure } 2 \text { about here }>>
$$

\section{Regional Management Autonomy and Product/Service Adaptation}

Regional management structures are established by MNCs primarily to meet the needs of regional customers (Rugman and Collinson, 2005). Such managerial support at the regional level may include, for example, regional cash management (Venzin, Kumar, and Kleine, 2008) or the coordination of regional production (Rugman and Collinson, 2004b). Therefore, according to Rugman (2005), a lack of market success can be partly explained by headquarters-based, centralized decision-making, which, "[...] may not always be appropriate to address region-specific challenges [that] may be better handled through region-based [...] organizational structures.“ Richter (2007) also provides evidence of the fact that regional activities prevent MNCs from suffering performance decreases, particularly during their initial foreign expansion. Consequently, it seems reasonable to hypothesize that increases in the decision-making autonomy of regional management should positively influence the regional performance of MNCs.

Hypothesis 1: Regional management autonomy is positively associated with regional success. 
The regional adaptation of products/services relates to the market strategies of MNCs, which in the case of international foreign market entries contributes to their sustained export performance (Calantone et al., 2006; Kotabe et al., 2009). Positive effects from market adaptations are mainly because of limitations in creating global products/services suitable for many countries, which is difficult and involves many pitfalls (Elango, 2004), given that customer preferences highly vary between regions (Malhotra et al., 2005). This suggests that the performance of MNCs is positively associated with the regional adaptations of products/services. The dependence of these performance effects on regional customer demands implies for MNCs that - in addition to back-end advantages from upstream FSAs - particularly "[...] strong downstream FSAs are necessary to achieve market success in the market considered, [...] at the national, regional, or inter-regional level" (Rugman et al., 2008a). Consequently, we hypothesize that increases in the regional adaptation of products/services should positively influence the regional performance of MNCs.

Hypothesis 2: Regional product/service adaptation is positively associated with regional success.

\section{Regional Orientation and Inter-Regional Distance}

An MNC's regional orientation is reflected in its regional geographic scope. Low degrees of a firm's regional orientation or in other words its broad geographic scope - measured by its spread of geographical and product markets entered - has been found to negatively moderate profitability increases resulting from its international expansion (Rugman, 2005; Vermeulen and Barkema, 2002). This is because a broader geographic scope strains the firm's absorptive capacity (Cohen and Levinthal, 1990), indicating that foreign expansions are easier to absorb by the MNC if they occur in 
countries that are "related" (Phene and Almeida, 2008; Rugman, 2005; Vermeulen et al., 2002). This explains why MNCs often expand by regions because each of them consists of "related" countries that are relatively close to one another (Ghemawat, 2005). At the same time MNCs allocate substantial decision-making autonomy to their regional management to better absorb, or exploit, the growing diversity of regional environmental developments and organizational resources (Enright, 2005a; Lehrer and Asakawa, 1999). A limited geographic scope, represented by a strong regional orientation, should facilitate this organizational learning of regional management in handling region-specific challenges (Rugman, 2005; Ruigrok and Wagner, 2003). Conversely, for MNCs with a high geographic scope, absorptive capacity constraints are salient that - even though the firm builds on an extensive internationalization experience and highly autonomous regional management in all regions - lead to an organizational and environmental complexity, which is extremely difficult to handle successfully (Bausch and Krist, 2007; Elango, 2004; Verbeke, Li, and Goerzen, 2009). As a result, the extent to which a high degree of regional management autonomy is effective at the regional level - meaning that it considerably contributes to the regional success of an MNC - is contingent upon the internal contextual variable regional orientation. This leads us to hypothesize that the regional orientation of an MNC should positively moderate the relationship $\mathrm{H} 1$ between regional management autonomy and regional success.

Hypothesis 3a: A firm's regional management autonomy will have a stronger impact on regional success given a higher regional orientation.

The regional orientation of an MNC also affects its successful regional product/service adaptation since its widespread geographic diversification may involve "[...] pitfalls similar to the conventional drawbacks of product diversification" (Rugman, 2005). Although MNCs are able to handle moderate levels of product diversification effectively, a high diversity in products and markets 
constrains their performance (Elango, 2004). Consequently, the degree to which an MNC can successfully adapt its products/services to each region is dependent upon the internal contingency variable regional orientation. More specifically, an MNC's increasing regional orientation should positively interact with the influence that regionally adapted products/services have on its regional success. As a result, it seems reasonable to hypothesize that the regional orientation of an MNC should positively moderate the relationship between regional product/service adaptation and regional success, as postulated in $\mathrm{H} 2$.

Hypothesis 3b: A firm's regional product/service adaptation will have a stronger impact on regional success given a higher regional orientation.

Considerable research has been directed to investigating the relationships between different indicators of inter-regional distance and the effectiveness of regional management in achieving regional market success. In light of a high geographic distance, increases in regional decisionmaking responsibilities have been found to be important to effectively explore regional markets (Yeung, Poon, and Perry, 2001). In addition, it has been shown that autonomous management is related to regional performance effects, if it leads to a better linkage of an MNC's institutional distance to its resources and structures (Venzin et al., 2008), reducing its liability of foreignness (Miller and Richards, 2002). The effectiveness of the regional management activities of MNCs is thereby highly contingent on their societal, cultural, and economic environment (Collinson et al., 2008; Rugman and Brain, 2004a). Consequently, negative performance effects from the risks and coordination costs of the MNC increase with the cultural heterogeneity in the firm's portfolio of international operations - mainly because of complexities in transferring management practices abroad and in adapting the firm's value chain activities to respective market requirements(Tong and Reuer, 2007). Inter-regional distance thereby can hamper the market-seeking expansion of MNCs in 
host regions if it is not associated with high regional management autonomy to link the MNC's “[...] existing knowledge base with host-region location advantages [...] which do not simply meld together without managerial intervention" (Rugman, 2005). Therefore, an increasing inter-regional distance faced by the MNC should positively interact with the degree to which increases in regional management autonomy lead to regional success. More specifically, we expect that the external contingency variable inter-regional distance has a positive moderating effect on the hypothesized relationship $\mathrm{H} 1$ between an MNC's regional management autonomy and its regional success.

Hypothesis 4a: A firm's regional management autonomy will have a stronger impact on regional success given a higher inter-regional distance.

This moderating effect of inter-regional distance also influences the successful regional adaptation of products/services because the size of these regional product/service adaptation investments is driven by "[...] home/host region differences in the cultural, administrative, geographic, and economic sphere [...]" (Rugman, 2005). Consequently, increases in the inter-regional distance faced by the MNC lead to rising costs from its liability of foreignness, which can be reduced by regionally adapted products/services, particularly by FSAs at the downstream end (Ohmae, 1985; Rugman, 2005; Rugman et al., 2008a). Given that these adaptations imposed by inter-regional distance are mainly related to the customer end, high risks for the $\mathrm{MNC}$ result from one-sided, upfront investments for adapting its products/services to host region demands. These high risks, however, have to be incurred by MNCs to achieve regional success, because cultural and economic differences between regions influence consumers' product/service choices as well as the diffusion and acceptance of new products/services (Kotabe et al., 2009; Malhotra et al., 2005). Therefore, the extent to which an MNC can successfully address regional demands by its regionally adapted products/services is contingent on the external contextual variable inter-regional distance. Based on 
this assumption we propose that increases in inter-regional distance should positively interact with the effect that a regional product/service adaptation has on the regional success of an MNC. Consequently, we expect that the inter-regional distance faced by an MNC should positively moderate the hypothesized relationship $\mathrm{H} 2$ between regional product/service adaptation and regional success.

Hypothesis 4b: A firm's regional product/service adaptation will have a stronger impact on regional success given a higher inter-regional distance.

In the following section, we will provide an overview about our sample and data and explain the measures of our independent and dependent variables. We then test our proposed model and explore the appropriate degree of regional management autonomy and regional product/service adaptations in MNCs.

\section{RESEARCH DESIGN AND METHODOLOGY}

\section{Sample and Data}

Our empirical analysis is based on data from MNCs, ranked as Fortune Global 500 firms in the period 2000-2008 by the magazine Fortune (2001-2009), resulting in a total sample of 663 companies. On the basis of the countries where the headquarters of our sample companies are located, we identified the home regions of these MNCs by using the UNCTAD methodology for the regional classification of countries (Arregle et al., 2009). This led to a continental perspective for the regional presence of these MNCs (Ghemawat, 2005), covering five regions: Africa, Asia-Pacific, Europe, North America, and South America. 
We compiled our secondary data from geographical segment reporting in annual reports and/or SEC filings. Our sample of 663 companies, during the nine-year period 2000-2008, provided 5,967 firmyear observations. For each of these years, we collected the geographically provided information of these firms - according to the five regions mentioned above. This was supplemented by an "other" category if this classification was not possible from the available data, which produced the necessary regional data to measure the constructs regional orientation and regional success of our research model. The primary data for the 663 sample companies were collected by means of survey-based, quantitative inquiry techniques. In the design of our questionnaire, we provided detailed definitions of the most important constructs (e.g., regional management autonomy, regional product/service adaptation, and inter-regional distance) and ensured that the survey was completed by the respondents for only one region - where their firm has been most successful (e.g., in terms of sales, profitability, and/or sales growth). This led to an application of our regional success factor model only to the most successful region of our sample firms - given either by their home region or by one of their foreign regions - which constitutes a meaningful approach for studying regional success factors.

To ensure that the survey was completed by respondents with a profound knowledge about the regional strategies of their firms, we directly contacted all $663 \mathrm{MNCs}$ of our sample via telephone. To identify appropriate key informants, we used the listings of Hoover's (2009) database and then targeted those MNC managers that are corporate experts for regional strategies. In particular, this included the managers at corporate headquarters who are responsible for the worldwide corporate strategies of their firms. After sending out our survey (mainly during the second quarter of 2009), we received 114 responses, corresponding to a response rate of $17.2 \%$. This is above the usual expected response rate of cross-national mail surveys of between 6\% and 16\% (Harzing, 1997, 2000), and thereby was perceived as satisfactory. Responses from 18 firms had to be eliminated 
because of incomplete or implausible answers, leading to 96 useable responses from the 663 sample companies (response rate 14.5\%), which we used in our research model. With respect to industry membership, our research sample was representative and the answers were tested for potential response biases.

\section{Measures}

We finally came up with a survey including 52 main questionnaire items that constituted the measurement models of the principal constructs, as depicted in Figure 3 of the Appendix. The reliability and validity of these measures were evaluated by means of respective quality criteria (Chin, 1998b). We used statements on five-point Likert scales to derive subjective estimates of responding MNC managers for the questionnaire items. Before sending out our survey, we tested the content and expert validity of the questionnaire items by means of an indicator's proportion of substantive agreement and by its substantive validity coefficient (Anderson and Gerbing, 1991). We also performed two subsequent in-depth pretests of our survey with 18 experts, highly recognized and experienced either in the area of regional strategies and/or with methodological issues in this area of research. In the following we provide an overview of the measures of our model.

\section{Regional Management Autonomy}

We measure the total degree of regional management autonomy by drawing on the most relevant dimensions of managerial decision-making autonomy of regional management centers, which may be granted in the areas of regional strategy development, regional market and product/service development, regional market coordination, and regional operational administration. Conversely, the degree of decision-making autonomy in each of these dimensions of regional managerial activities influences the overall extent to which regional management can autonomously decide at 
the regional level (Ohmae, 1985). Drawing on this rationale, a formative direction of causality exists between the four dimensions and regional management autonomy. Given that these four dimensions are formulated at a similar level of abstraction and cannot be observed directly (Chin, 1998a), they represent latent first-order variables in the nomological network of the latent second-order construct regional management autonomy. Consequently, as illustrated in Figure 3, the multidimensional latent construct regional management autonomy is measured at the level of the latent first-order variables.

\section{Regional product/service adaptation}

As indicated above, a MNC may regionally adapt its products/services in the areas of design, functional scope, offering portfolio, and brands. The extent to which a MNC realizes an adaptation of downstream and upstream FSAs along these four dimensions, determines the MNC's overall regional product/service adaptation to regional requirements and conditions. Thus a change in one of these four dimensions should cause a change in the resulting regional product/service adaptation, illustrating the formative direction of causality between the four dimensions and regional product/service adaptation. This is confirmed by Albers and Götz (2006) who show that the market orientation, or responsiveness, of a firm should be modeled in a formative manner, if it is achieved by a set of different strategic measures. Here, the regional market responsiveness of the MNC is expressed by the degree of its regional product/service adaptation that - as a latent second-order construct - is realized by four different strategic measures, or dimensions, at a similar level of abstraction (Chin, 1998a). The resulting nomological network between the four dimensions and the latent second-order variable - as illustrated in Figure 3 - requires a measurement model at the level of the four not directly observable, first-order constructs (Chin, 1998a), regional design, regional functional scope, regional offering portfolio, and regional brands. 


\section{Regional Orientation}

A MNC's regional orientation is reflected by three indicators of this latent construct, including a market-related and an activity-related regional orientation. Furthermore, due to the fact that the regional orientation reflects a firm-internal, regiocentric orientation of MNC managers towards the region as a potential market (Wind et al., 1973), a subjective estimation of MNC managers of this market-related regional orientation represents another important indicator of this latent variable. While this subjective estimate is derived from our survey, the objective measurement of the MNCs' market-related regional orientation is measured by the distribution of sales across economic regions - whereas its activity-related regional orientation is also assessed objectively by the regional dispersion of its assets (Goerzen et al., 2007; Oh, 2009; Rugman, 2005; Rugman et al., 2004c). All three manifest variables indicate different degrees of a MNC's regional orientation, which is assumed to decrease from home-regional to host-regional, from host-regional to bi-regional, and from bi-regional to multi-regional (global).

\section{Inter-regional Distance}

As indicated above, the inter-regional distance faced by a MNC is a latent moderating variable, which is observed by its manifest variables indicating an inter-regional cultural, administrative/political/institutional, geographic, and economic distance. The inter-regional distance - based on all of the different firm-external, environmental elements represented by its indicators - can substantially increase the liability of foreignness of MNCs, which results in costs and investments to complement their existing FSAs with new, location-bound FSAs and CSAs (Rugman, 2005). 


\section{Regional Corporate Success}

The organizational and strategic effectiveness of MNCs at the global level is usually measured by their corporate success, for example by their return on investment, profit, or other performance variables (Donaldson, 2001; Zeithaml et al., 1988). An MNC's effectiveness at the regional level depends on factors such as its particular regional product/service offering, certain regional performance variables, regional management configurations, and specific contingency variables. We conceptualize the effectiveness at the regional level as regional corporate success, consisting of three different variables. The first regional performance metric, often applied by regionalization scholars, is the percentage of intra-regional sales, meaning the relationship between sales revenue within a particular region and the total sales revenue of the MNC (e.g., Richter, 2007).

Even though this geographical dispersion of sales indicates an MNC's ability to successfully penetrate regional markets (Rugman et al., 2004c, 2008a), an important additional condition besides sales-based success should be fulfilled. As stated by Rugman (2005), "[...] ultimately it is market penetration (if achieved in a profitable way) that provides the best, in fact the only, indicator of global corporate success." Consequently, the profitability that an MNC realizes in a particular region is a second important indicator of regional corporate success. Here, relative figures should also be utilized - given by the ratio of regional profits to total profits - to assess the degree of relative importance of this region's profitability in comparison to total firm profits. Besides a success indicator of downstream FSAs - given by the ratio of regional sales to total sales - a third regional success indicator has to be considered. According to Rugman and Verbeke (2008a), this is the ratio of regional assets to total assets. The measures of this geographical dispersion of both the sales and the assets of MNCs reflect the outcome of regional strategies and structures in the form of downstream and upstream FSAs (Rugman et al., 2008a). 
With respect to the prevailing criticism of such relative regional performance measures (e.g., Asmussen, 2009), we argue that - in comparison to other MNCs - a relatively higher portion of regional revenue, profits, or assets in a certain region corresponds to a higher contribution to the firm's overall performance. Taking into consideration that all the firms ranked in the Fortune Global 500 listing are, by definition, very successful companies in the markets where they generate their sales, a relatively higher regional contribution to the firm's total sales, profits or assets shows that this $\mathrm{MNC}$ is more successful within this region than other firms. In other words, a firm within this sample that realizes a higher contribution to its total performance by means of its regional sales, profits or assets than another company is more successful within this region than another firm operating in the same region. Consequently, we believe that these relative metrics are well suited for assessing the regional performance of MNCs.

The three firm-specific regional corporate success indicators presented are contingent on the internal and external organizational context of MNCs. Consequently, regional corporate success in this paper is regarded as the result of a "fit" of appropriate degrees of firm-specific regional management autonomy (as regards managerial decisions) and regional product/service adaptation (as regards product attributes/service elements) with interaction effects from the internal regional orientation of the MNC and its external inter-regional distance.

\section{Controls}

To assure that the relationships postulated in our model are not affected by additional influences, control variables are used. In our study, two control variables seem particularly relevant: an MNC's firm size and its regional competition. Although firm size can have an impact on regional performance by its influence on the geographic scope of MNCs (Beleska-Spasova and Glaister, 
2009), regional competition in the form of intra-regional and/or foreign competitive attacks may affect regional corporate success by triggering different strategic responses by the firm (Hutzschenreuter and Gröne, 2009).

\section{Research Methodology}

We applied SEM as the analytical methodology to investigate the causal relationships in our regional success factor model. Of the relevant SEM techniques, we applied the PLS approach (Lohmöller, 1984, 1989; Wold, 1966). This was particularly because of the advantages of PLS over alternative SEM methods in component-based predictive modeling (Chin and Newsted, 1999; Henseler, Ringle, and Sinkovics, 2009), which qualifies for its application particularly in the early stages of research and theory development. Because the theoretical basis for the relationships among our latent variables - regional management autonomy, regional product/service adaptation, regional orientation, inter-regional distance, and regional success - is still at an early stage in the international business field, PLS qualifies as a modeling technique for our study. Furthermore, the PLS algorithm allows the estimation of moderating effects from interaction variables because it does not require that the error terms of the indicator variable are uncorrelated, which poses a problem with other SEM techniques such as LISREL (Chin, Marcolin, and Newsted, 2003). The consideration of such moderating influences is of particular importance for international business research involving a contingency view on theoretical models such as our regional success factor model, where contextual influences are assumed to affect the regional strategy-performance relationship.

The empirical testing in our study sequentially analyzed the two types of relationships between the latent variables in Figure 2. First, we estimated the direct effects of the exogenous variables regional management autonomy and regional product/service adaptation as well as of the contextual 
variables regional orientation and inter-regional distance on the endogenous construct regional success (basic regional success factor model). Second, we estimated the moderating effects that emanate from the latent contingency variables regional orientation (H3a and H3b) and inter-regional distance ( $\mathrm{H} 4 \mathrm{a}$ and $\mathrm{H} 4 \mathrm{~b})$ on the relationships of the basic model (extended regional success factor model). The ability of these specified models to describe the relationships between the observed variables is the main focus in the quality evaluation of structural equation models (Chin, 1998b). Thus, apart from evaluating the explanatory power and predictive ability of the structural model, the reliability of parameter estimations is evaluated by the significance of factor loadings in terms of their t-values (Chin, 1998b). To calculate t-values, the resampling procedure bootstrapping is applied (Chin, 1998b; Efron and Tibshirani, 1993).

\section{RESULTS}

\section{Basic Regional Success Factor Model}

In evaluating the basic regional success factor model (Figure 4 and Table 2), we observe that the portion of explained construct variance for regional success reaches a moderate level of 0.46. Furthermore, the effect size of the independent variables on regional success reaches small to medium values. The required significance level of at least $5 \%$ in the two-sided t-test is achieved by all latent constructs - apart from regional management autonomy and regional orientation, both significant at the $10 \%$ level. These results imply that all latent first-order variables of regional product/service adaptation are important defining characteristics of this multidimensional construct. With respect to our research hypotheses, the sign of the path coefficient for regional product/service adaptation, recognizing its significance level of 5\%, provides strong support for $\mathrm{H} 2$ - whereas $\mathrm{H} 1$ is rejected at the $10 \%$ significance level by the respective sign for regional management autonomy. Moreover, we observe the direct effects of the contextual variables regional orientation and inter- 
regional distance on regional success, which in the case of the former are positive and significant at the $10 \%$ level and strongly negative at the $1 \%$ significance level for the latter. After introducing the control variables firm size and regional competition, only minor changes to the hypothesized relationships are observed. $\mathrm{H} 2$ is still supported - even though only at the $10 \%$ significance level whereas the hypothesized relationship in $\mathrm{H} 1$ is rejected now at the $5 \%$ significance level. Consequently, the overall predictive ability of the basic structural model is considerable, which is supported by notable values of the Stone-Geisser test of almost 0.3 .

$$
\begin{aligned}
& <<\text { place Figure } 4 \text { about here }>> \\
& <<\text { place Table } 2 \text { about here }>>
\end{aligned}
$$

\section{Extended Regional Success Factor Model}

In the extended regional success factor model (Figure 5, Table 3), the consideration of interaction effects leads to a substantial increase in the endogenous variable's coefficient of determination to a value of 0.63 . The effect size of the exogenous and interaction variables on regional success reaches small to high values. In addition, almost all latent variables - apart from regional product/service adaptation, regional orientation, and the interaction variable of regional orientation and regional management autonomy - reach the required significance level of at least $5 \%$ in the two-sided t-test. Once more, this implies the importance of all latent first-order variables of regional product/service adaptation as defining characteristics of this multidimensional construct. Concerning our research hypotheses, $\mathrm{H} 1$ is rejected again - now at the $1 \%$ significance level - whereas $\mathrm{H} 2$ is not supported. This is because even though the sign of the path coefficient of regional product/service adaptation confirms $\mathrm{H} 2$, the respective t-value is not significant. Furthermore, the signs of the path coefficients of the interaction variables of regional orientation and regional product/service adaptation, and of inter-regional distance and regional product/service adaptation, which are both at significance levels 
of $5 \%$, provide strong support for $\mathrm{H} 3 \mathrm{~b}$ and $\mathrm{H} 4 \mathrm{~b}$. This means that the positive relationship between an MNC's regional product/service adaptation and its regional success is strongly positively affected by its regional orientation and its inter-regional distance. At the same time, however, the signs of the path coefficients for the other interaction variables point in the opposite direction of the research hypotheses, implying that $\mathrm{H} 3 \mathrm{a}$ and $\mathrm{H} 4 \mathrm{a}$ are rejected. The rejection of $\mathrm{H} 4 \mathrm{a}$ - which relates to the interaction variable of inter-regional distance and regional management autonomy - is significant at the $10 \%$ level. In addition, we notice the direct effects of the moderating variables on regional success, which are marginally positive and not significant in the case of regional orientation, whereas strongly negative for inter-regional distance at the 5\% significance level. In the case of the extended model, the introduction of the control variables firm size and regional competition also leads to only minor changes in the hypothesized relationships. Again, H1 is rejected - now with significance at the 5\% level - and $\mathrm{H} 2$ is also not supported, once again because of its missing significance. The hypothesized relationships in $\mathrm{H} 3 \mathrm{~b}$ and $\mathrm{H} 4 \mathrm{~b}$ are confirmed with a significance of the former at the 5\% level and the latter at the 10\% level. Furthermore, $\mathrm{H} 3 \mathrm{a}$ and $\mathrm{H} 4 \mathrm{a}$ are rejected once again, but these rejections were not significant. Thus, the extended structural model has a high overall predictive ability, which is supported by high values of the Stone-Geisser test of almost 0.4.

$$
\begin{aligned}
& <\text { <lace Figure } 5 \text { about here }>> \\
& <<\text { place Table } 3 \text { about here }>>
\end{aligned}
$$

\section{DISCUSSION: IMPLICATIONS FOR THEORY AND PRACTICE}

This paper aimed to explore success the factors of regional strategies for MNCs by investigating the appropriate degree of regional management autonomy and regional product/service adaptation. Although research on regional strategies has increased over the past decade, the core question of our paper has not been answered sufficiently so far. Against this background our study is, to the best of 
our knowledge, the first that explores the interactions between regional success factors and MNC performance based on a longitudinal study including not only secondary but also primary data on a large sample of Fortune Global 500 firms. We also advance theory in international business by applying SEM as an analytical methodology to investigate the causal relationships in our regional success factor model which has not been performed so far in this field of research. Based on this we can draw a number of interesting conclusions for theory and practice.

Contrary to $\mathrm{H} 1$ and the mainstream literature on regionalization (Rugman, 2005; Rugman et al., 2008a), our results suggest that high degrees of regional management autonomy granted by an MNC have a weakly significant negative impact on its regional success. One can think of several reasons why this may be the case. First, these adverse performance effects may be explained by the fact that high regional management autonomy can lead to inefficiencies in coordination and control (Bartlett et al., 1989) - where regionally decentralized decision-making exceeds the degree that is necessary for the efficient management of regional products/services. In other words, the growth of benefits from additional, regional managerial efforts to address customer preferences at the downstream end of MNCs' value chains does not compensate for the growth in its associated costs (Proff, 2000). Second, decision-making by corporate headquarters gives subsidiaries the impression that the MNC is interested in their affairs (Vora, Kostova, and Roth, 2007) - which in the case of considerable intermediate layers of coordination and control by regional management may have adverse effects, with negative performance implications.

Our empirical results suggest that, consistent with $\mathrm{H} 2$, a firm's regional adaptation of its products/services has a highly significant positive impact on its regional success. This supports the contention of other regionalization scholars that regions and the specific demands of customers, governments, and other stakeholders have to be considered in MNCs' products/services to succeed in regional markets (Rugman, 2005; Rugman et al., 2004c, 2008a). Concerning the elements that 
constitute the regional strategies of $\mathrm{MNCs}$, we found that the regional design, the regional functional scope, the regional offering portfolio, and the regional brands of their products/services highly influence the degree of regional adaptation. This supports the proposition that MNCs - for the successful penetration of geographical regions - have to develop region-bound FSAs to adapt their market strategy approach to regional requirements and conditions (Rugman, 2005; Rugman et al., 2008a). The ability of MNCs to develop region-specific capabilities thereby can highly contribute to the explanation of their regional market success with their product/service offering, both within and beyond their home region. More generally, this implies that MNCs achieve an optimal mix or moderate levels of global integration and national responsiveness by means of different combinations of these four region-bound FSAs in the regional adaptation of their products/services. The processes of an MNC's value creation by its regional product/service adaptation based on regional FSAs should thereby receive utmost attention in regionalization theory and its scholarly reflection on regional firm strategies.

With respect to the organizational and environmental context faced by regionally operating MNCs, we found that the internal context in the form of their regional orientation has a positive direct influence on their regional success, whereas the external context given by their inter-regional distance exerts a direct negative effect on their regional performance. This may be explained by the fact that an MNC's high orientation, or focus, on only one particular region and its low interregional distance lead to low organizational and environmental complexity - resulting in a low interregional liability of foreignness, which contributes to the survival of MNCs (Ghemawat, 2008; Rugman, 2005; Verbeke et al., 2009).

Concerning the interaction effect of the regional orientation of $\mathrm{MNCs}(\mathrm{H} 3 \mathrm{a}$ and $\mathrm{H} 3 \mathrm{~b}$ ), our results provide no support for its influence, hypothesized in $\mathrm{H} 3 \mathrm{a}$, on the relationship between their regional management autonomy and regional success, where this internal contextual variable seems to have 
almost no impact at all. However, we found a highly significant positive interaction effect for the hypothesized impact in $\mathrm{H} 3 \mathrm{~b}$ of an MNC's regional orientation on the relationship between its regional product/service adaptation and its regional performance. This shows that the regional orientation of a firm seems to be relatively unimportant for the impact that its regional management autonomy has on regional success, whereas the performance effects from its regional product/service adaptation are highly positively affected by this internal contingency. The latter finding can be explained by the fact that the narrow geographic market focus of MNCs, given by their strong regional orientation, supports the development of those FSAs in the regional adaptation of their products/services - which are capable of highly satisfying customer needs within the region, leading to positive effects on regional success (Rugman, 2005; Rugman et al., 2008a). In other words, MNCs with a geographically limited regional focus seem to be able to use their region-bound capabilities more effectively as regards the successful regional adaptation of their products/services. This effective employment of their region-bound FSAs also reduces the MNCs' overall amount of one-sided, location-specific investments at the customer-end - which are required for the regional adaptation of their products/services (Rugman, 2005) - constituting a further positive effect on regional performance. Conversely, the reduced regional orientation of MNCs seem to lower their ability, first, to mentally absorb such increases in their multinationality, and second - as a consequence - to effectively develop those FSAs required for a successful regional product/service adaptation.

The rejection of H4a means that the negative impact that highly autonomous regional management has on the regional success of MNCs is reduced in the case of high inter-regional distance. Conversely, in the case of low inter-regional distance, the negative performance effects that result from highly autonomous management persist to a large part because they are only reduced marginally by low values of this external context of the MNC. These relationships can be explained 
by several reasons. First, at low levels of inter-regional distance, MNCs face only a minor liability of foreignness where their respective familiarity with regional demands and requirements does not require a high allocation of decisions at the regional level (Yeung et al., 2001; Zaheer and Mosakowski, 1997). Therefore, because no discernible benefits are expected from a high level of regional management autonomy its negative influence on a firm's regional performance largely remains. Second, if an MNC is exposed to high inter-regional distance, a delegation of decisionmaking to regional management may contribute to reducing uncertainties related to the economic, socio-cultural, and business environment, which facilitates the successful exploitation of regional FSAs (Collinson et al., 2008). This effect alleviates the negative impact that regional management autonomy has on regional success. Third, at increased levels of inter-regional distance, higher decision-making responsibilities at the regional level can contribute to the better coordination of intra-regional operations (Enright, 2005b; Ricart et al., 2004), for example in national subsidiaries or regional production and distribution hubs (Buckley et al., 2004). The coordinative support of autonomous regional managers in reaping such regional agglomeration benefits contributes to reducing the negative effect of a high regional management autonomy on performance (Arregle et al., 2009; Rugman et al., 2001c). Overall, these explanations show that - in light of increases in an MNC's inter-regional distance - decision-making by regional management involves benefits that mitigate its negative effects on regional performance. At the same time, however, the low interregional distances of MNCs may imply that decision-making by corporate headquarters and/or national subsidiaries creates more regional value than highly autonomous regional management (Ghemawat, 2005). This external contingency thereby contributes to the theoretical explanation of limitations and opportunities in the delegation of decision-making autonomy to the regional level.

The strong confirmation of $\mathrm{H} 4 \mathrm{~b}$ indicates that the regional adaptation of products/services becomes increasingly important for regional success in the case of rising levels of inter-regional distance. 
This is consistent with existing accounts of regionalization theory that MNCs - which face high inter-regional differences in the various markets they serve - need to establish a regional insider position for their regionally adapted products/services to be successful (Ohmae, 1985; Rugman, 2005; Rugman et al., 2004c). MNCs realize these product/service adaptations mainly by their regional FSAs. This means that region-specific capabilities, particularly those at the customer end that enable the deep penetration of markets (Millar, Choi, and Chen, 2005; Rugman, 2005), need to be employed to successfully address inter-regional differences. The costs for developing such regional FSAs as well as the associated location-bound investments for melding them with CSAs at the regional level seem to pay off in light of high inter-regional differences, given the associated positive regional performance effects. Consequently, the MNCs' commitment to distant foreign host regions - given by the development of region-specific FSAs for the regional adaptation of their products/services - constitutes an important element in their successful regional expansions across borders. Therefore, and more generally, the interaction effect of inter-regional distances on the successful regional product/service adaptations of MNCs lays the platform for a broad theoretical basis for the explanation of firms' cross-border expansions into distant regions.

Furthermore, after the consideration of the interaction effects of an MNC's regional orientation and its inter-regional distance, we found that $\mathrm{H} 1$ is again rejected, given the highly significant negative relationship between an MNC's regional management autonomy and its regional success. At the same time, however, we could not find support for the hypothesized positive relationship in $\mathrm{H} 2$ between an MNC's regional product/service adaptation and its regional success even though this was confirmed earlier in the absence of interaction effects from organizational and environmental contingencies. An MNC's successful product/service adaptation thereby seems to be highly dependent upon both its internal and external context - as shown by the strong support for H3b and H4b. This indicates that the regional market strategies of MNCs should correspond to the 
requirements of the organizational and environmental context they face. Therefore, MNCs' development of those FSAs that are necessary for their successful regional product/service adaptations is highly contingent upon these contextual influences. In other words, an MNC's successful regional product/service adaptation seems to highly depend upon achieving a proper regional environment-strategy-structure fit. This seems only partly true for an MNC's regional management autonomy, whose impact on regional success was only found to be weakly negatively affected by the external contingency inter-regional distance (H4a), whereas a firm's regional orientation exerted no notable influence on this relationship (H3a). More specifically, the influence of an MNC's regional management autonomy on its regional performance seems to be exclusively dependent upon its inter-regional distance, indicating a weaker form of the regional environmentstrategy-structure fit. In general, however, this implies that there is no universal "best way" for implementing regional strategies, nor that their realization is solely situation-specific.

\section{CONCLUSION, LIMITATIONS, AND AVENUES FOR FUTURE RESEARCH}

Our findings suggest that low degrees of regional management autonomy and high levels of regional product/service adaptation are appropriate for MNCs to be regionally successful. The possible adverse effects of high degrees of regional management autonomy on regional success are mitigated by an MNC's inter-regional distance. Furthermore, our results indicate that the regional performance associated with high levels of regional product/service adaptation is positively influenced by both an MNC's regional orientation and its inter-regional distance. These research findings imply that MNCs should optimize their regional success by varying their regional management autonomy and regional product/service adaptation in light of their organizational and environmental context. Although we hope that the findings of our study make a valuable contribution to the existing knowledge in theory and practice about the framing and implementation of regional strategies in 
MNCs, the results and implications of our study need to be interpreted with caution, because they are subject to several limitations.

As in many studies in this field, our data are limited to Fortune Global 500 firms, which results in a bias of our findings towards large companies. Furthermore, our sample size constrains the generalizability of our findings. In addition, the applied methods of data collection can be challenged about their potential biases in the managerial perceptions of our primary data, as well as accounting and tax distortions in our secondary data. The timely consistency of our research is limited by the fact that our secondary data relate to the years 2000-2008, whereas our primary data were collected in 2009. Moreover, the PLS method has methodological disadvantages, which other statistical methods could have avoided, and this might have led to different results.

In future research, the application of qualitative research designs for such analyses - such as case studies or interviews - could lead to a more fine-grained understanding of the firm- and sectorspecific nature of the success factors of regional strategies. Researchers could also direct the research perspective towards small and medium-sized firms, geographical levels other than the region, and/or to the perceptions of national and/or regional managers instead of the corporate headquarters of MNCs. Finally, there is a rich avenue of work to be pursued on how region-specific capabilities - such as our identified four FSAs, the regional design, regional functional scope, regional offering portfolio, and/or regional brands of products/services - are linked to regionbound/location-bound advantages in the form of CSAs. Any of these research avenues could lead to a more profound understanding of the success factors of regional strategies. Such insights would further advance the existing knowledge in the field about how the regional extent of the market can be translated into an improved geographic competitiveness of MNCs by "[...] appropriate strategies at the level of each broad region [...]" (Rugman, 2009). 


\section{REFERENCES}

Albers S, Götz O. 2006. Messmodelle mit Konstrukten zweiter Ordnung in der betriebswirtschaftlichen Forschung. Die Betriebswirtschaft 66 (6): 669-677.

Anderson JC, Gerbing DW. 1991. Predicting the performance of measures in a confirmatory factor analysis with a pretest assessment of their substantive validities. Journal of Applied Psychology 76 (5): $732-$ 740 .

Arregle J-L, Beamish PW, Hébert L. 2009. The regional dimension of MNEs' foreign subsidiary localization. Journal of International Business Studies 40 (1): 86-107.

Asmussen CG. 2009. Local, regional, or global? Quantifying MNE geographic scope. Journal of International Business Studies 40 (7): 1192-1205.

Banalieva ER, Santoro MD. 2009. Local, regional, or global? Geographic orientation and relative financial performance of emerging market multinational enterprises. European Management Journal 27 (5): 344-355.

Bartlett CA, Ghoshal S. 1989. Managing across borders: The transnational solution. Harvard Business School Press: Boston, MA.

Bausch A, Fritz T, Boesecke K. 2007. Performance effects of internationalization strategies: A meta-analysis. In Regional aspects of multinationality and performance, AM Rugman (ed.). Elsevier: Amsterdam; 143-176.

Bausch A, Krist M. 2007. The effect of context-related moderators on the internationalization-performance relationship: Evidence from meta-analysis. Management International Review 47 (3): 319-347.

Beleska-Spasova E, Glaister KW. 2009. The geography of British exports: Country-level versus firm-level evidence. European Management Journal 27 (5): 295-304.

Buckley PJ, Clegg J, Forsans N, Reilly KT. 2001. Increasing the size of the "country": Regional economic integration and foreign direct investment in a globalised world economy. Management International Review 41 (3): 251-274.

Buckley PJ, Ghauri PN. 2004. Globalisation, economic geography and the strategy of multinational enterprises. Journal of International Business Studies 35 (2): 81-98.

Calantone RJ, Kim D, Schmidt JB, Cavusgil ST. 2006. The influence of internal and external firm factors on international product adaptation strategy and export performance: A three-country comparison. Journal of Business Research 59 (2): 176-185. 
Chin WW. 1998a. Issues and opinion on structural equation modeling. Management Information Systems Quarterly 22 (1): vii-xvi.

Chin WW. 1998b. The partial least squares approach to structural equation modeling. In Modern methods for business research, GA Marcoulides (ed.). Lawrence Erlbaum Associates: Mahwah, NJ; 295-336.

Chin WW, Marcolin BL, Newsted PR. 2003. A partial least squares latent variable modeling approach for measuring interaction effects: Results from a Monte Carlo simulation study and an electronic-mail emotion/adoption study. Information Systems Research 14 (2): 189-217.

Chin WW, Newsted PR. 1999. Structural equation modeling analysis with small samples using partial least squares. In Statistical strategies for small sample research, RH Hoyle (ed.). Sage: Thousand Oaks, CA; 307-342.

Cohen WM, Levinthal DA. 1990. Absorptive capacity: A new perspective on learning and innovation. Administrative Science Quarterly 35 (1): 128-152.

Collinson S, Rugman AM. 2008. The regional nature of Japanese multinational business. Journal of International Business Studies 39 (2): 215-230.

De Búrca S, Fletcher R, Brown L. 2004. International marketing: An SME perspective. Financial Times Prentice Hall: Harlow.

Delios A, Beamish PW. 2005. Regional and global strategies of Japanese firms. Management International Review 45 (1): 19-36.

Donaldson L. 2001. The contingency theory of organizations. Sage: Thousand Oaks, CA.

Doz YL, Prahalad CK. 1991. Managing diversified MNCs: A search for a new paradigm. Strategic Management Journal 12 (Special issue 1): 145-164.

Dunning JH. 2001. Global capitalism at bay? Routledge: London.

Efron B, Tibshirani RJ. 1993. An introduction to the bootstrap. Chapman \& Hall: New York, NY.

Elango B. 2004. Geographic scope of operations by multinational companies: An exploratory study of regional and global strategies. European Management Journal 22 (4): 431-441.

Enright MJ. 2005a. Regional management centers in the Asia-Pacific. Management International Review 45 (1): 59-82.

Enright MJ. 2005b. The roles of regional management centers. Management International Review 45 (1): 83 102. 
Feils DJ, Rahman M. 2008. Regional economic integration and foreign direct investment: The case of NAFTA. Management International Review 48 (2): 147-163.

Fortune. 2001-2009. The Fortune Global 500. F1-F10.

Ghemawat P. 2001. Distance still matters: The hard reality of global expansion. Harvard Business Review 79 (8): 137-147.

Ghemawat P. 2003. Semiglobalization and international business strategy. Journal of International Business Studies 34 (2): 138-152.

Ghemawat P. 2005. Regional strategies for global leadership. Harvard Business Review 83 (12): 98-108.

Ghemawat P. 2007. Why the world isn't flat. Foreign Policy 159 (Mar/Apr): 54-61.

Ghemawat P. 2008. Redefining global strategy: Crossing borders in a world where differences still matter. Harvard Business School Press: Boston, MA.

Girod SJG, Rugman AM. 2005. Regional business networks and the multinational retail sector. Long Range Planning 38 (4): 335-357.

Goerzen A, Asmussen CG. 2007. The geographic orientation of multinational enterprises and its implications for performance. In Regional aspects of multinationality and performance, AM Rugman (ed.). Elsevier: Amsterdam; 65-83.

Harzing A-W. 1997. Response rates in international mail surveys: Results of a 22-country study. International Business Review 6 (6): 641-665.

Harzing A-W. 2000. Cross-national industrial mail surveys: Why do response rates differ between countries? Industrial Marketing Management 29 (3): 243-254.

Henseler J, Ringle CM, Sinkovics RR. 2009. The use of partial least squares path modeling in international marketing. In New challenges to international marketing, RR Sinkovics, PN Ghauri (eds.). Emerald Group Publishing Limited: Bingley; 277-319.

Hoover's. 2009. Company information. http://www.hoovers.com (1 September 2009).

Hutzschenreuter T, Gröne F. 2009. Product and geographic scope changes of multinational enterprises in response to international competition. Journal of International Business Studies 40 (7): 1149-1170.

Keillor BD, Hult GTM, Kandemir D. 2004. A study of the service encounter in eight countries. Journal of International Marketing 12 (1): 9-35. 
Kotabe M, Jiang CX. 2009. Contemporary research trends in international marketing: The 2000s. In The Oxford handbook of international business, AM Rugman (ed.). Oxford University Press: Oxford; 447501.

Kotler P, Armstrong G. 2004. Principles of marketing. Pearson Prentice Hall: Upper Saddle River, NJ.

Lehrer M, Asakawa K. 1999. Unbundling European operations: Regional management and corporate flexibility in American and Japanese MNCs. Journal of World Business 34 (3): 267-286.

Li L. 2005. Is regional strategy more effective than global strategy in the US service industries? Management International Review 45 (1): 37-57.

Li L, Li D. 2007. Testing the global and regional strategies of multinational enterprises. In Regional aspects of multinationality and performance, AM Rugman (ed.). Elsevier: Amsterdam; 263-296.

Lohmöller J-B. 1984. LVPLS, program manual. Latent variables path analysis with partial least-squares estimation. Zentralarchiv für empirische Sozialforschung: Köln.

Lohmöller J-B. 1989. Latent variable path modeling with partial least squares. Physica-Verlag: Heidelberg.

Malhotra NK, Ulgado FM, Agarwal J, Shainesh G, Wu L. 2005. Dimensions of service quality in developed and developing economies: Multi-country cross-cultural comparisons. International Marketing Review 22 (3): 256-278.

Millar CCJM, Choi CJ, Chen S. 2005. Globalization rediscovered: The case of uniqueness and "creative industries". Management International Review 45 (1): 121-128.

Miller SR, Richards M. 2002. Liability of foreignness and membership in a regional economic group: Analysis of the European Union. Journal of International Management 8 (3): 323-337.

Morrison AJ, Ricks DA, Roth K. 1991. Globalization versus regionalization: Which way for the multinational? Organizational Dynamics 19 (3): 17-29.

Morrison AJ, Roth K. 1992. The regional solution: An alternative to globalization. Transnational Corporations 1 (2): 37-55.

Oh CH. 2009. The international scale and scope of European multinationals. European Management Journal 27 (5): 336-343.

Ohmae K. 1985. Triad power: The coming shape of global competition. Free Press: New York, NY.

Onkvisit S, Shaw J. 2009. International marketing: Strategy and theory. Routledge: London.

Phene A, Almeida P. 2008. Innovation in multinational subsidiaries: The role of knowledge assimilation and subsidiary capabilities. Journal of International Business Studies 39 (5): 901-919. 
Prahalad CK, Doz YL. 1987. The multinational mission: Balancing global integration with local responsiveness. Free Press: New York, NY.

Proff H. 2000. Hybrid strategies as a strategic challenge - The case of the German automotive industry. Omega 28 (5): 541-553.

Proff H. 2002. Business unit strategies between regionalisation and globalisation. International Business Review 11 (2): 231-250.

Ricart JE, Enright MJ, Ghemawat P, Hart SL, Khanna T. 2004. New frontiers in international strategy. Journal of International Business Studies 35 (3): 175-200.

Richter N. 2007. Intra-regional sales and the internationalization and performance relationship. In Regional aspects of multinationality and performance, AM Rugman (ed.). Elsevier: Amsterdam; 359-381.

Rugman AM. 2000. The end of globalization. Random House: London.

Rugman AM. 2003a. The regional solution: Triad strategies for multinationals. Business Horizons 46 (6): 3 6.

Rugman AM. 2003b. Regional strategy and the demise of globalization. Journal of International Management 9 (4): 409-417.

Rugman AM. 2005. The regional multinationals: MNEs and "global" strategic management. Cambridge University Press: Cambridge.

Rugman AM. 2009. Is international business strategy global or regional? European Management Journal 27 (5): 293-294.

Rugman AM, Brain C. 2004a. Regional strategies of multinational pharmaceutical firms. Management International Review 44 (Special issue 3): 7-25.

Rugman AM, Collinson S. 2004b. The regional nature of the world's automotive sector. European Management Journal 22 (5): 471-482.

Rugman AM, Collinson S. 2005. Multinational enterprises in the new Europe. Are they really global? Organizational Dynamics 34 (3): 258-272.

Rugman AM, Hodgetts R. 2001a. The end of global strategy. European Management Journal 19 (4): 333 343.

Rugman AM, Moore K. 2001b. The myths of globalization. Ivey Business Journal 66 (1): 64-68.

Rugman AM, Oh CH. 2007. Multinationality and regional performance, 2001-2005. In Regional aspects of multinationality and performance, AM Rugman (ed.). Elsevier: Amsterdam; 31-43. 
Rugman AM, Verbeke A. 1998. Multinational enterprises and public policy. Journal of International Business Studies 29 (1): 115-136.

Rugman AM, Verbeke A. 2001c. Subsidiary-specific advantages in multinational enterprises. Strategic Management Journal 22 (3): 237-250.

Rugman AM, Verbeke A. 2004c. A perspective on regional and global strategies of multinational enterprises. Journal of International Business Studies 35 (1): 3-18.

Rugman AM, Verbeke A. 2005. Towards a theory of regional multinationals: A transaction cost economics approach. Management International Review 45 (1): 3-15.

Rugman AM, Verbeke A. 2008a. A regional solution to the strategy and structure of multinationals. European Management Journal 26 (5): 305-313.

Rugman AM, Verbeke A. 2008b. The theory and practice of regional strategy: A response to Osegowitsch and Sammartino. Journal of International Business Studies 39 (2): 326-332.

Ruigrok W, Wagner H. 2003. Internationalization and performance: An organizational learning perspective. Management International Review 43 (1): 63-83.

Takeuchi H, Porter ME. 1986. Three roles of international marketing in global strategy. In Competition in global industries, ME Porter (ed.). Harvard Business School Press: Boston, MA; 111-146.

Tong TW, Reuer JJ. 2007. Real options in multinational corporations: Organizational challenges and risk implications. Journal of International Business Studies 38 (2): 215-230.

Venzin M, Kumar V, Kleine J. 2008. Internationalization of retail banks: A micro-level study of the multinationality-performance relationship. Management International Review 48 (4): 463-485.

Verbeke A. 2009. International business strategy: Rethinking the foundations of global corporate success. Cambridge University Press: Cambridge.

Verbeke A, Kenworthy TP. 2008. Multidivisional vs metanational governance of the multinational enterprise. Journal of International Business Studies 39 (6): 940-956.

Verbeke A, Li L, Goerzen A. 2009. Toward more effective research on the multinationality-performance relationship. Management International Review 49 (2): 149-161.

Vermeulen F, Barkema HG. 2002. Pace, rythm, and scope: Process dependence in building a profitable multinational corporation. Strategic Management Journal 23 (7): 637-653.

Vora D, Kostova T, Roth K. 2007. Roles of subsidiary managers in multinational corporations: The effect of dual organizational identification. Management International Review 47 (4): 595-620. 
Westney DE. 2006. Book review of "the regional multinationals: MNEs and 'global' strategic management". Journal of International Business Studies 37 (3): 445-449.

Wind Y, Douglas SP, Perlmutter HV. 1973. Guidelines for developing international marketing strategies. Journal of Marketing 37 (2): 14-23.

Wold H. 1966. Estimation of principal components and related models by iterative least squares. In Multivariate analysis, PR Krishnaiah (ed.). Academic Press: New York, NY; 391-420.

Yeung HW-C, Poon J, Perry M. 2001. Towards a regional strategy: The role of regional headquarters of foreign firms in Singapore. Urban Studies 38 (1): 157-183.

Yin E, Choi CJ. 2005. The globalization myth: The case of China. Management International Review 45 (1): 103-120.

Yip GS, Rugman AM, Kudina A. 2006. International success of British companies. Long Range Planning 39 (3): 241-264.

Zaheer S. 1995. Overcoming the liability of foreignness. Academy of Management Journal 38 (2): 341-363.

Zaheer S. 2002. The liability of foreignness, redux: A commentary. Journal of International Management 8 (3): 351-358.

Zaheer S, Mosakowski E. 1997. The dynamics of the liability of foreignness: A global study of survival in financial services. Strategic Management Journal 18 (6): 439-463.

Zeithaml VA, Varadarajan PR, Zeithaml CP. 1988. The contingency approach: Its foundations and relevance to theory building and research in marketing. European Journal of Marketing 22 (7): 37-64. 


\section{APPENDIX}

$<<$ place Figure 3 about here $>>$ 


\section{FIGURES AND TABLES}

\section{FIGURE 1}

Forms of regional product/service adaptation (Onkvisit and Shaw, 2009; Emrich, 2007; Keillor, Hult, and Kandemir, 2004; Takeuchi and Porter, 1986, 1989)

- Esthetic product attributes

- Symbolic product attributes

- Horizontal adaptation

- Functional product attributes

- Physical product attributes

- Physical good quality

- Service quality

- Servicescape

- Vertical adaptation

- Universal products

- Modified products

- Country-specific products
Categories of regional product/service adaptation

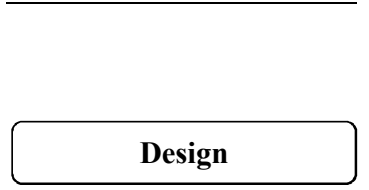

Functional scope

Brands

Offering portfolio
Reasons for regional product/service adaptation (Onkvisit and Shaw, 2009; Búrca, Fletcher, and Brown, 2004)

- Own language and symbolism

- Own style and design preferences

- Local customs and culture

- Taste requirements

- Environmental conditions

- Regulations and standards

- Physical appearance of society

- Room and space restrictions

- Regional usage conditions

- Performance standards

- Usage habits

- Income level

- Level of innovation

- Historically developed preferences

\section{Categories of regional product/service adaptation}




\section{FIGURE 2}

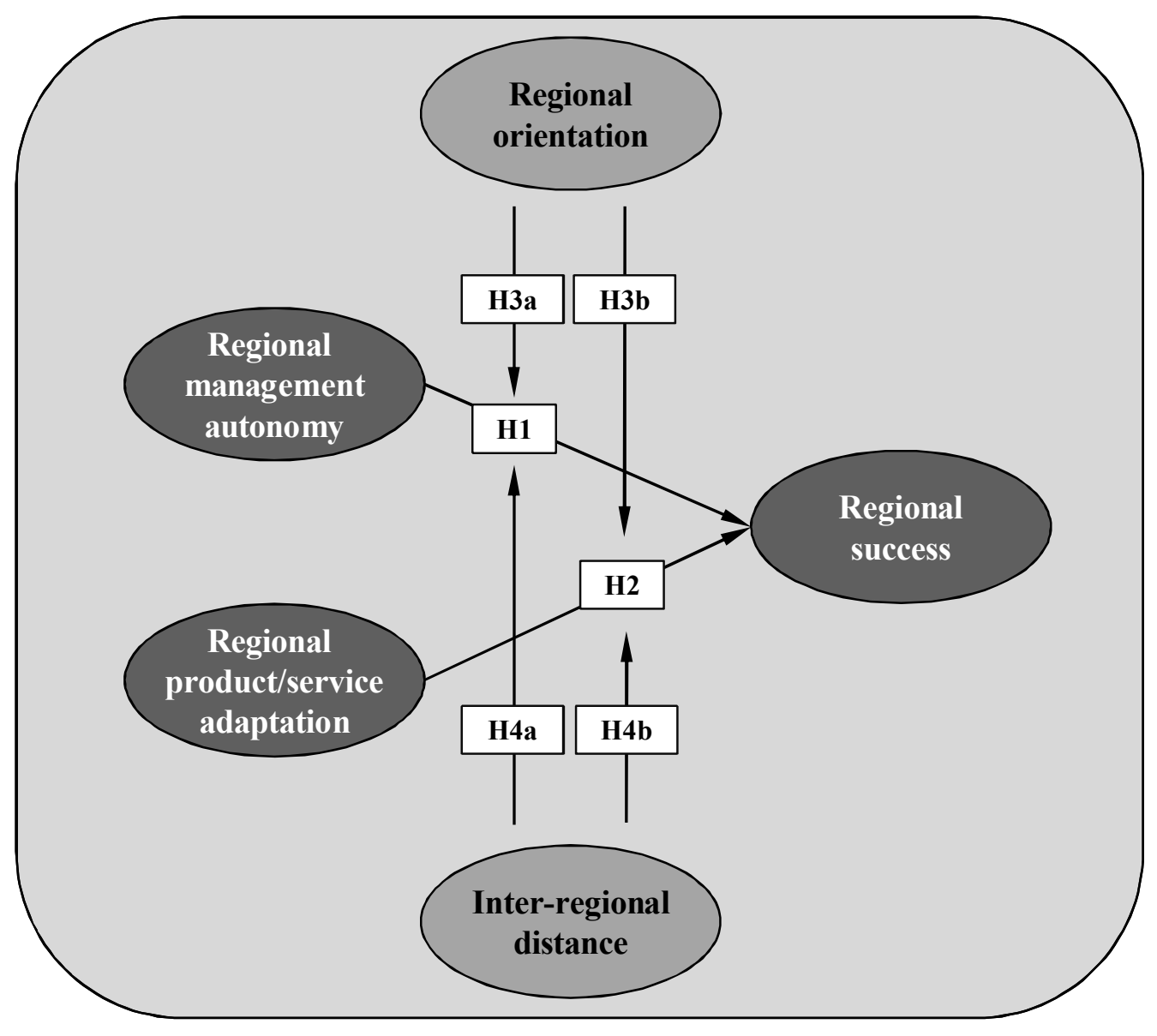

Regional success factor model 


\section{FIGURE 3}

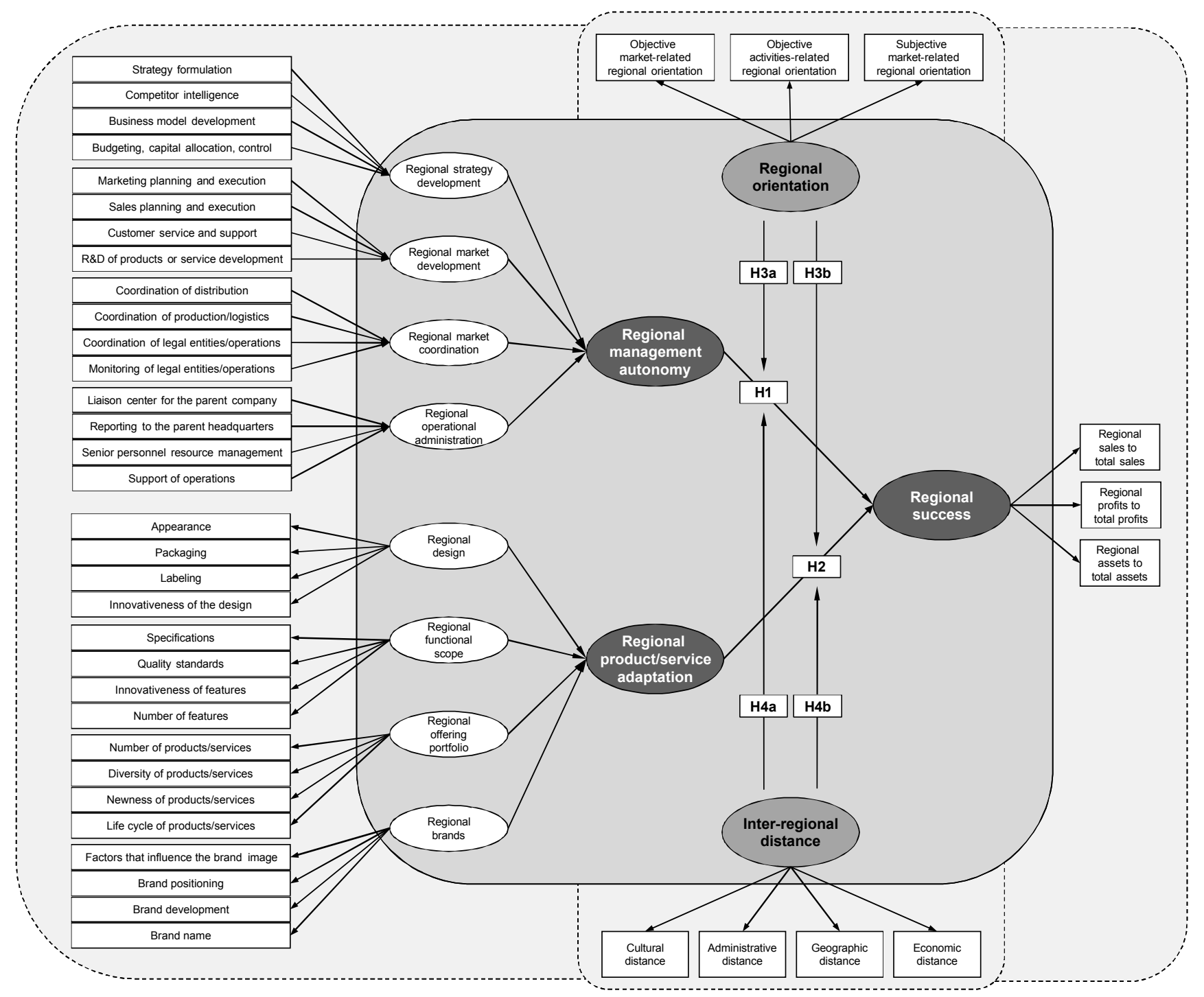

\section{Measurement model}


FIGURE 4

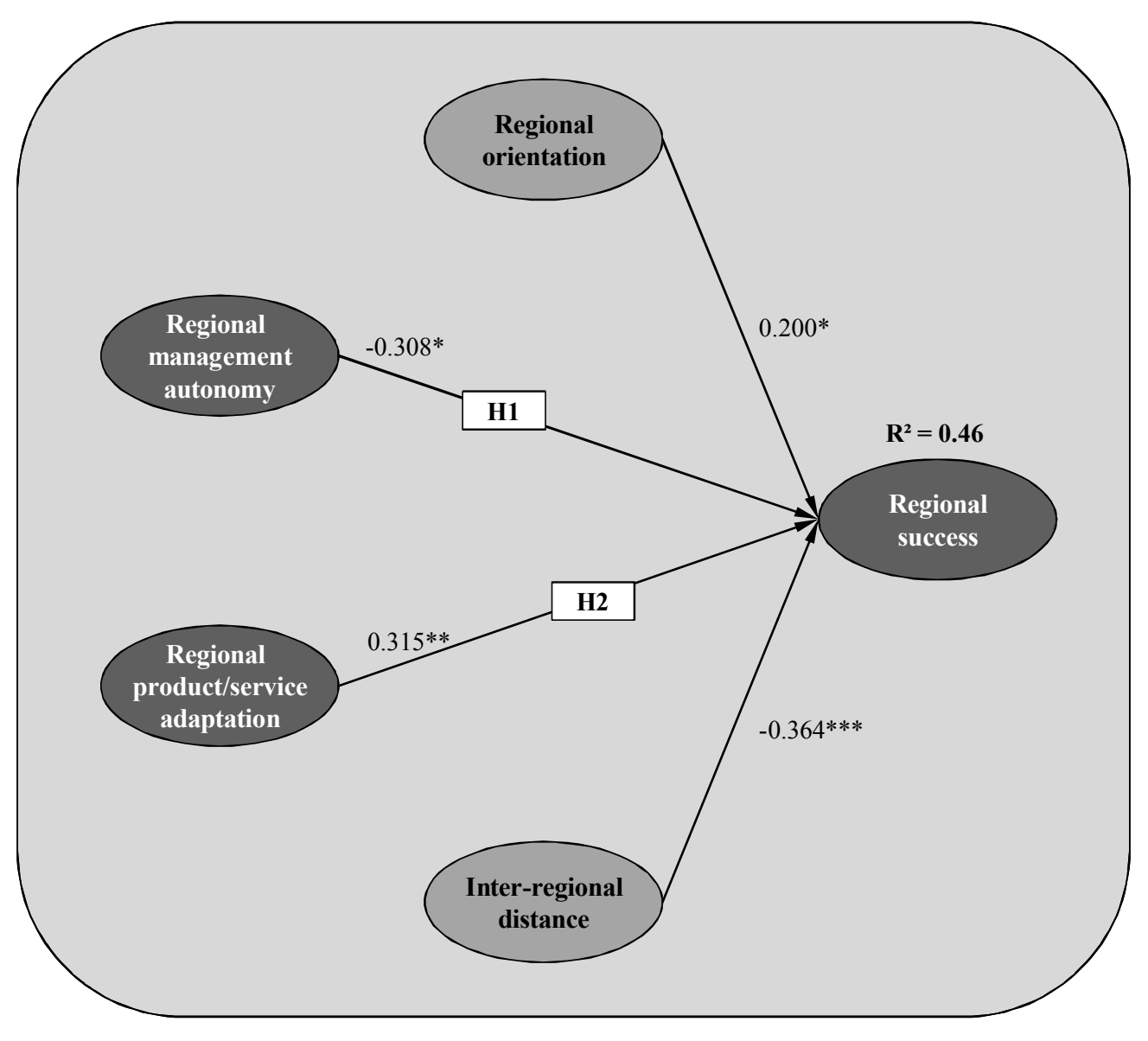

Basic regional success factor model 


\section{FIGURE 5}

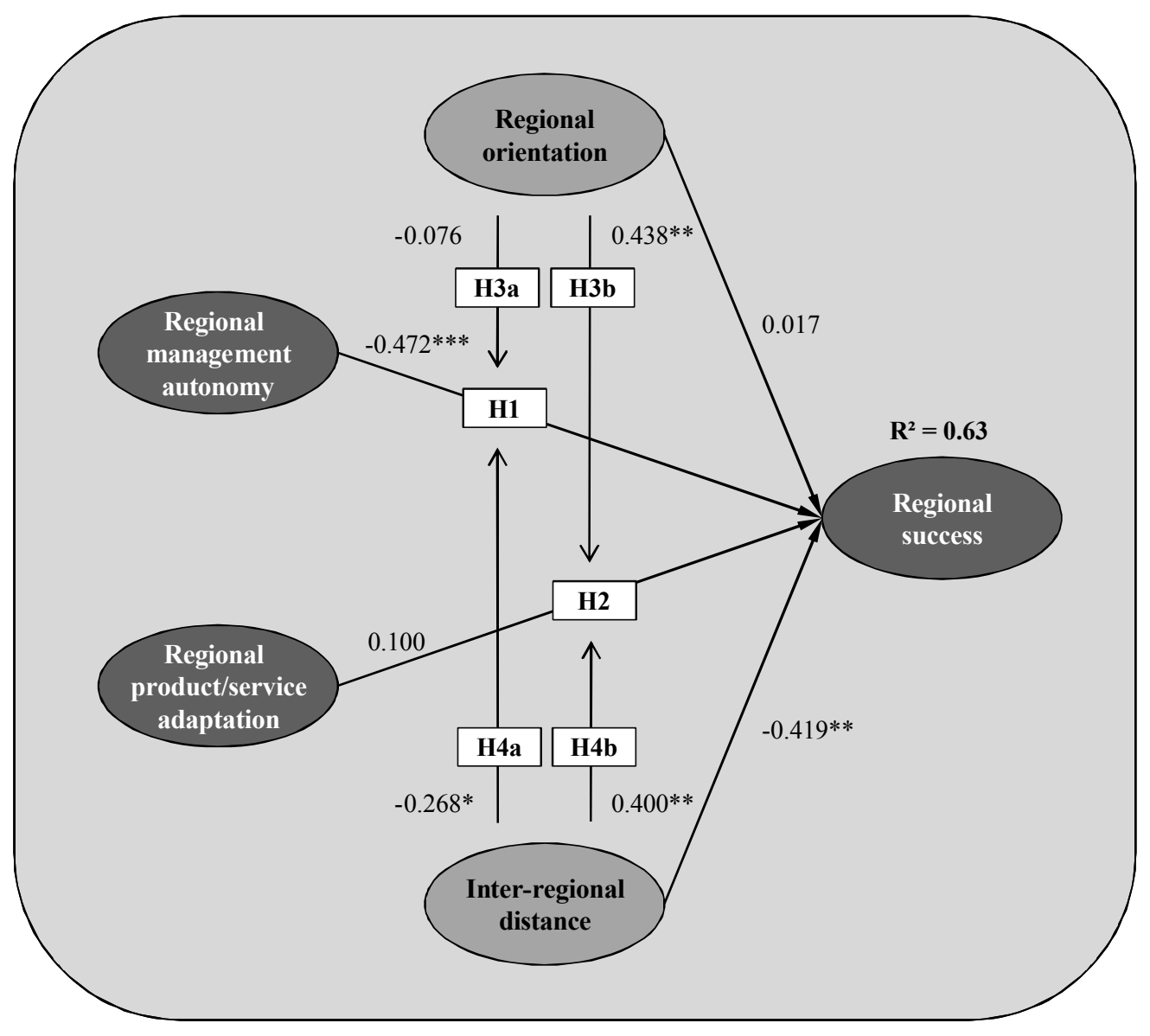

Extended regional success factor model 
TABLE 1

\section{Dimensions of inter-regional distance}

\begin{tabular}{|c|c|c|c|}
\hline \multicolumn{4}{|c|}{ Inter-regional distance } \\
\hline $\begin{array}{l}\text { Cultural } \\
\text { distance }\end{array}$ & $\begin{array}{c}\text { Administrative/political/ } \\
\text { institutional distance }\end{array}$ & $\begin{array}{c}\text { Geographic } \\
\text { distance }\end{array}$ & $\begin{array}{l}\text { Economic } \\
\text { distance }\end{array}$ \\
\hline $\begin{array}{l}\text { - Different languages } \\
\text { - Different ethnicities; } \\
\text { lack of connective } \\
\text { ethnic or social } \\
\text { networks } \\
\text { - Different religions } \\
\text { - Level of trust } \\
\text { - Different values, social } \\
\text { norms, and dispositions }\end{array}$ & $\begin{array}{l}\text { - Lack of colonial ties } \\
\text { - Lack of shared regional } \\
\text { trading bloc (monetary } \\
\text { or political association) } \\
\text { - Lack of common } \\
\text { - Purrency } \\
\text { - Golitical hostility } \\
\text { - Institutional weakness }\end{array}$ & $\begin{array}{l}\text { - Physical distance, } \\
\text { remoteness } \\
\text { - Lack of a common } \\
\text { (land) border } \\
\text { - Lack of sea or river } \\
\text { access } \\
\text { - Size of country/region } \\
\text { - Weak transportation or } \\
\text { communication links } \\
\text { - Differences in time } \\
\text { zones } \\
\text { - Differences in climates } \\
\text { and disease } \\
\text { environments }\end{array}$ & $\begin{array}{l}\text { - Differences in consumer } \\
\text { incomes (rich-poor } \\
\text { differences) } \\
\text { - Other differences in } \\
\text { costs and quality of } \\
\text { - Natural resources } \\
\text { - Financial resources } \\
\text { - Human resources } \\
\text { - Infrastructure } \\
\text { - Intermediate inputs } \\
\text { - Information or } \\
\text { knowledge }\end{array}$ \\
\hline
\end{tabular}


TABLE 2

Evaluation of the basic structural model

\begin{tabular}{|c|c|c|c|c|c|c|}
\hline Model & Latent constructs & $\mathbf{R}^{2}$ & Effect size & $\begin{array}{c}\text { Path } \\
\text { coefficients } \\
\end{array}$ & t-values & $\begin{array}{c}\text { Stone- } \\
\text { Geisser-test }\end{array}$ \\
\hline \multirow{9}{*}{$\begin{array}{c}\text { Basic } \\
\text { structural } \\
\text { model }\end{array}$} & Regional management autonomy & & 0.162 & -0.308 & $1.893^{*}$ & \\
\hline & Regional product/service adaptation & & 0.171 & 0.315 & $2.190^{\star \star}$ & \\
\hline & \begin{tabular}{|l|} 
Regional design \\
\end{tabular} & & & 0.282 & $7.689^{* \star \star}$ & \\
\hline & Regional functional scope & & & 0.295 & $4.086^{* \star \star}$ & \\
\hline & Regional offering portfolio & & & 0.205 & $6.099^{* \star \star}$ & \\
\hline & \begin{tabular}{|l} 
Regional brands \\
\end{tabular} & & & 0.438 & $5.736^{* \star \star *}$ & \\
\hline & Regional orientation & & 0.065 & 0.200 & $1.675^{\star}$ & \\
\hline & Inter-regional distance & & 0.220 & -0.364 & $3.238^{\star \star \star}$ & \\
\hline & Regional success & 0.460 & & & & 0.292 \\
\hline \multirow{11}{*}{$\begin{array}{c}\text { Basic } \\
\text { structural } \\
\text { model incl. } \\
\text { control } \\
\text { variables }\end{array}$} & Regional management autonomy & & 0.129 & -0.290 & $2.017^{\star \star}$ & \\
\hline & Regional product/service adaptation & & 0.134 & 0.277 & $1.905^{*}$ & \\
\hline & \begin{tabular}{|l|} 
Regional design \\
\end{tabular} & & & 0.281 & $6.727^{* \star \star *}$ & \\
\hline & Regional functional scope & & & 0.294 & $4.235^{* * *}$ & \\
\hline & \begin{tabular}{|l|} 
Regional offering portfollio \\
\end{tabular} & & & 0.205 & $5.703^{\text {tox }}$ & \\
\hline & \begin{tabular}{|l} 
Regional brands \\
\end{tabular} & & & 0.439 & $6.371^{* \star *}$ & \\
\hline & Regional orientation & & 0.077 & 0.213 & 1.562 & \\
\hline & Inter-regional distance & & 0.134 & -0.311 & $2.366^{\star *}$ & \\
\hline & Regional success & 0.489 & & & & 0.284 \\
\hline & Firm size & & 0.053 & -0.183 & 1.391 & \\
\hline & Regional competition & & 0.009 & 0.073 & 0.565 & \\
\hline
\end{tabular}


TABLE 3

\section{Evaluation of the extended structural model}

\begin{tabular}{|c|c|c|c|c|c|c|}
\hline Model & Latent constructs & $\mathbf{R}^{2}$ & Effect size & $\begin{array}{c}\text { Path } \\
\text { coefficients } \\
\end{array}$ & t-values & $\begin{array}{c}\text { Stone- } \\
\text { Geisser-test }\end{array}$ \\
\hline \multirow{13}{*}{$\begin{array}{c}\text { Extended } \\
\text { structural } \\
\text { model }\end{array}$} & Regional management autonomy & & 0.403 & -0.472 & $2.972^{* \star *}$ & \\
\hline & Regional product/service adaptation & & 0.020 & 0.100 & 0.456 & \\
\hline & Regional design & & & 0.282 & $5.309^{\star \star *}$ & \\
\hline & Regional functional scope & & & 0.295 & $4.060^{* \star *}$ & \\
\hline & Regional offering portfolio & & & 0.205 & $4.813^{\star \star \star}$ & \\
\hline & Regional brands & & & 0.438 & $5.252^{* \star \star}$ & \\
\hline & Regional orientation & & 0.001 & 0.017 & 0.122 & \\
\hline & Inter-regional distance & & 0.399 & -0.419 & $2.518^{* *}$ & \\
\hline & Regional orientation $\mathrm{x}$ regional management autonomy & & 0.013 & -0.076 & 0.586 & \\
\hline & Regional orientation $\mathrm{x}$ regional product/service adaptation & & 0.312 & 0.438 & $2.533^{\star \star}$ & \\
\hline & Inter-regional distance $\mathrm{x}$ regional management autonomy & & 0.104 & -0.268 & $1.886^{*}$ & \\
\hline & Inter-regional distance $\mathrm{x}$ regional product/service adaptation & & 0.268 & 0.400 & $2.041^{* *}$ & \\
\hline & Regional success & 0.625 & & & & 0.414 \\
\hline \multirow{15}{*}{$\begin{array}{c}\text { Extended } \\
\text { structural } \\
\text { model incl. } \\
\text { control } \\
\text { variables }\end{array}$} & Regional management autonomy & & 0.383 & -0.455 & $2.188^{* *}$ & \\
\hline & Regional product/service adaptation & & 0.014 & 0.084 & 0.363 & \\
\hline & Regional design & & & 0.282 & $8.528^{\star \star \star}$ & \\
\hline & Regional functional scope & & & 0.295 & $4.112^{\star \star \star}$ & \\
\hline & Regional offering portfolio & & & 0.205 & $5.329^{\star \star \star}$ & \\
\hline & Regional brands & & & 0.438 & $7.628^{\star \star \star}$ & \\
\hline & Regional orientation & & 0.003 & 0.041 & 0.175 & \\
\hline & Inter-regional distance & & 0.300 & -0.404 & $1.887^{*}$ & \\
\hline & Regional orientation $\mathrm{x}$ regional management autonomy & & 0.024 & -0.106 & 0.492 & \\
\hline & Regional orientation $\mathrm{x}$ regional product/service adaptation & & 0.284 & 0.415 & $2.136^{\star \star}$ & \\
\hline & Inter-regional distance $\mathrm{x}$ regional management autonomy & & 0.116 & -0.284 & 1.392 & \\
\hline & Inter-regional distance $\mathrm{x}$ regional product/service adaptation & & 0.246 & 0.390 & $1.715^{\star}$ & \\
\hline & Regional success & 0.640 & & & & 0.395 \\
\hline & Firm size & & 0.016 & -0.093 & 0.445 & \\
\hline & Regional competition & & 0.024 & 0.103 & 0.697 & \\
\hline
\end{tabular}

